\title{
Tip-1 Diyabet Oluşturulan Siçanların Kas Dokusunda Bazı Biyokimyasal Değişikliklere Karşı Çam Yağının Etkisi
}

\author{
Ersin DEMİR ${ }^{1 *}$ Ökkeș YILMAZ ${ }^{2}$ \\ ${ }^{*}$ *Düzce Üniversitesi, Ziraat ve Doğa Bilimleri Fakültesi, Tartmsal Biyoteknoloji Bölümü, 81620/DÜZCE, TÜRKIYE \\ ${ }^{2}$ Firat Üniversitesi, Fen Fakültesi, Biyoloji Bölümü, 23119/ELAZIĞ, TÜRKIYE
}

\begin{abstract}
ÖZET
Bu çalışma, Tip-1 diyabet oluşturulan sıçanlarda çam yağının kas dokusundaki bazı biyokimyasal parametreler üzerine etkisinin araştırılması için tasarlandı. Sıçanlar kontrol (K), streptozotosin (STZ) ve streptozotosin+çam yăğ (STZ+ÇY) olmak üzere üç grubu ayrıldı. STZ gruplarına intraperitoneal enjeksiyonla streptozotosin $(65 \mathrm{mg} / \mathrm{kg})$ verilerek diyabet oluşturuldu. Çam yağı grubundaki sıçanlara haftada iki gün $1 \mathrm{~mL} / \mathrm{kg}$ dozunda intraperitoneal enjeksiyonla çam yağı, ayrıca deney boyunca çam yağı $(0,5 \mathrm{~mL} / 500 \mathrm{~mL})$ içme suyuna eklenerek verildi. Kontrol grubuna göre, STZ grubunda MDA düzeyinin anlamlı bir şekilde arttığ $1(p<0,001)$, GSH ve total protein düzeyinin $(p<$ $0,001)$ anlamlı bir şekilde azaldığı belirlendi, STZ grubu ile karşılaştırıldığında, uygulanan çam yağı sonucunda MDA düzeyinin anlamlı bir şekilde azaldığ $(p<0,001)$, GSH ve total protein düzeyinin anlamlı bir şekilde arttığ $(p<0,001)$ tespit edildi. Kontrol grubuna göre, STZ grubunda yağ asidi kompozisyonu, A, D, E ve K vitaminleri, kolesterol ve sterol düzeyinde önemli değişikliklerin olduğu, uygulanan çam yağının bu değişiklikleri önemli ölçüde engelleyebildiği saptand. Elde ettiğimiz bulgulara göre, çam yağının kas dokusunda deneysel diyabetin neden olduğu bazı biyokimyasal metabolik düzensizliklerin azaltılmasında yararlı etkileri olduğu ortaya çıkmıştır.
\end{abstract}

Anahtar kelimeler: Deneysel diyabet, oksidatif stres, yağ asidi kompozisyonu, A, D, E ve K vitaminleri, kolesterol ve sterol

\section{Effects of Pine Oil Aganist Some Biochemical Parametres Occurring Muscle Tissue of The Rats Induced Type-1 Diabetes}

\begin{abstract}
The present study was designed to evaluate the impact of pine oil on some biochemical parameters in muscle tissue of streptozotocin-induced type-1diabetic rats. The rats were divided into three groups: control (C) streptozotocin (STZ), streptozotocin+pine oil (STZ+PO) grups. Diabetes induced in rats by a single intraperitoneal injection of streptozotocin $(65 \mathrm{mg} / \mathrm{kg}) .1 \mathrm{~mL} / \mathrm{kg}$ the dose pine oil was intraperitoneally injected twice in a week to the streptozotocin+pine oil (STZ+PO), and additionally $0.5 \mathrm{~mL} / 500 \mathrm{~mL}$ dose of pine oil was added to drinking water of these group. MDA levels of muscle tissue was increased significantly $(\mathrm{p}<0,001)$ in STZ group and glutathione (GSH) level muscle tissue was decreased significantly $(\mathrm{p}<0,001)$ when compared to control group. It was detected that MDA levels of muscle tissue significantly was decreased $(\mathrm{p}<0,001)$ and GSH level was significantly $(\mathrm{p}<0,001)$ inreased in the STZ+PO group compared to STZ group. The fatty acid composition, A, D, E and K vitamins, cholesterol and sterol levels significantly were changed in the control group compared to STZ group, in addition to, the applied pine oil can significantly inhibited these changes in muscle tissue. According to our findings, it was observed that the pine oil has beneficial effects in the decreasing of some biochemical metabolic disorders caused by experimental diabetes in the muscle tissue.
\end{abstract}

Keywords: Experimental diabetes, oxidative stress, fatty acid composition, A, D, E and K vitamins, cholesterol and sterols

\section{Giriş}

Diabetes mellitus, pankreasın yeterli miktarda insülin hormonu üretmemesi ya da ürettiği insulin hormonunun etkili bir şekilde kullanılamaması ya da her ikisi kusura bağlı olarak gelişen ve yüksek kan glukoz düzeyi ile karakterize metabolik bir hastalıktır. Antik çağlarda diyabet, "tatlı idrar" ve "aşırı kas kaybı" ile bağlantılı bir hastalık olarak teşhis edilmiştir. Bugün diyabet dünya genelinde yaklaşık olarak 170 milyondan fazla insanı etkilemekle birlikte, 2030 yılında 365 milyondan fazla kişiye etkileyeceği ve yaygın kronik hastalıklardan bir haline geleceği öngörülmektedir [1].

Diyabetin doku ve organ metabolizması üzerindeki zararlı 
etkileri iyi bilinmekle birlikte, kontrolsüz hipergliseminin doku ve organların yapı ve fonksiyonlarını etkileyerek işlev ve fonksiyon kayıplarına yol açtığı bir gerçektir. İnsülin, anabolik hormonların en önemlisidir, bu nedenle insülin metabolizmasında ortaya çıkan bozukluklar sadece dokuların glikoz metabolizmasını değil, aynı zamanda, yağ ve protein metabolizmasını da etkilemektedir [2]. Kas dokusu insüline bağlı olarak glukoz kullandığı için insülin metabolizmasında ortay çıkan bozukluklardan en çok etkilenen dokuların başında yer alır. Bu nedenle kas kaybı, kas güçsüzlüğü ve atrofisi diyabet ile karakterize önemli belirtilerdir. Deneysel ve doğal diyabette, iskelet kasında ortaya çıkan kayıplar protein katabolizmasındaki artış ile birlikte görülmektedir [3].

Diyabet ile ilişkili komplikasyonların patolojisinde artmış ya da kontrolsüz oksidatif stres merkezi role sahiptir. Hiperglisemi, vücutta serbest radikaller ile antioksidanlar arasında bulunan dengeyi bozarak reaktif oksijen türlerinin artmasina, antioksidan savunma sisteminin aktivitesinin azalmasina sebep olmaktadır [3].

Streptozotosin (STZ), deney hayvanlarında deneysel diyabet oluşturmada yaygın olarak kullanılan diyabetojenik bir bileşiktir. STZ’nin, yapısında glukoz molekülü bulunduğundan dolayı pankreasta bulunan beta hücrelerine GLUT-2 vasitasıyla alınır ve DNA alkilasyonuna neden olur. Bunu DNA tamiri izler ve tamir sırasında görev alan poli polimeraz hücre içindeki nikotinamid adenin dinükleotidi (NAD) kullanarak NAD depolarını boşaltır ve ATP içeriğini azaltır. Böylece hücresel enerji depolarının tükenmesi beta hücrelerinde nekroza yol açar. Streptozotosin uygulamasından sonrası pankreasta insülin üreten hücrelerde serbest radikaller olarak adlandırılan bileşiklerin üretiminde artış olmakta ve sonuçta beta hücrelerinde nekrozis oluşumu neticesinde bu hücrelerin insülin üretme kapasitelerinin bozulmasına bağlı olarak deneysel diyabet durumu ortaya çıkmaktadır [4,5].

Çam türleri Akdeniz ve İran-Turan bölgelerinin en yaygın tıbbi bitkilerden biridir. Türkiye'de çam türlerinde elde edilen droglar özellikle antiseptik, balgam sökücü, solunum ve üriner sistem hastalıkları, romatizma ağrıları ve cilt hastalıklarına karşı kullanılmaktadır $[6,7,8]$. Aynı zamanda şeker hastalığına karşıda faydalı olduğu ifade edilmiştir [9,10]. Pinus türlerinin kesin olarak yüksek biyolojik aktiviteye sahip olduğu ve bu nedenle gıda ve ilaç sektörlerinde kullanılmak üzere büyük bir potansiyelinin olduğu yapılan çalışmalarda ortaya çıkmıştır [11]. Çin, Japonya, Hindistan, Rusya ve Kazakistan gibi ülkelerde bazı sağlık problemlerine karşı çamın; kabuk, iğne ve reçine özütlerinin halk arasında yaygın olarak kullanıldığı ifade edilmiştir [12].

$\mathrm{Bu}$ çalışmada diyabetin kas dokusunda oksidatif stres, yağ asidi ve $A, D, E$ ve $K$ vitaminleri, kolesterol ve bazı steroller üzerinde oluşturduğu biyokimyasal değişiklikler ile bu değişikliklere karşı çam yağının etkisinin incelenmesi amaçlanmıştır.

\section{Materyal ve Metot}

\subsection{Deneysel diyabetin oluşturulmast}

Bu çalışmada 30 adet 8-10 haftalık Wistar albino ırkı erkek sıçanlar kullanıldı. Deneyde kullanılacak sıçanlar rastgele kontrol (K), streptozotosin (STZ) ve streptozotosin+çam yağ 1 (STZ+ÇY) olmak üzere üç gruba ayrıldı. Diyabet oluşturmak için STZ ve STZ+ÇY grubunu oluşturan tüm siçanlara 65 $\mathrm{mg} / \mathrm{kg}$ dozunda STZ (Sigma-Aldrich (St. Louis, MO, USA)) fosfat-sitrat tampon ( $0.1 \mathrm{M}, \mathrm{pH} 4.5)$ çözülerek intraperitoneal enjeksiyonla verildi [13]. STZ enjeksiyonundan 72 saat sonra tüm sıçanlar bir gece önceden aç bırakıldı. Aç bırakılan sıçanların kuyruk veninden alınan kanın glukometre cihazında (Smart Chek) okunması suretiyle açlık kan glikoz düzeyleri ölçüldü. Açlık kan glikoz düzeyi $250 \mathrm{mg} / \mathrm{dl}$ ya da üzeri olan sıçanlar tip-1 diyabet olarak kabul edildi [13]. Deneysel uygulamalar, Frrat Üniversitesi Hayvan Deneyleri Etik Kurulu'ndan onay alınarak gerçekleştirildi (Karar no: 2011/81). Çalışma sekiz hafta sürdü ve çalışmanın sonunda tüm sıçanlar dekapite edildi.

\section{2 Çam yağının hazırlanması}

Çam yağının ticari formu kullanıldı (Kırıntı BaharatAktariye) ve dimetil sülfoksitte (DMSO) bire bir oranında çözüldü (v/v). Bu karışım STZ+ÇY grubuna haftada iki gün $1 \mathrm{~mL} / \mathrm{kg}$ dozunda intraperitoneal enjeksiyonla, ayrıca içme suyuna çam yağ $(0.5 \mathrm{~mL} / 500 \mathrm{~mL})$ eklenerek verildi [14]. STZ ve kontrol grubu sıçanlarına haftada iki gün $1 \mathrm{~mL} /$ $\mathrm{kg}$ dozunda intraperitoneal enjeksiyonla DMSO verildi. $\mathrm{Bu}$ çalışmada sıçanların arka bacak kısmından elde edilen iskelet kası doku örnekleri kullanıldı ve bu örnekler analiz yapılıncaya kadar $-86^{\circ} \mathrm{C}$ de muhafaza edildi.

\subsection{Doku homojenatının hazırlanmast}

Grupların kas doku örnekleri, Tris-HCl, Trisbase ve EDTA (pH:7,4) tamponu ile homojenize edildikten sonra $+4^{\circ} \mathrm{C}$ 'de $9050 \times$ g'de 20 dakika (dk) santrifüj edilerek doku pelletinden ayrıld1 [14]. Elde edilen supernatant kısım MDA, indirgenmiş glutatyon (GSH) ve total protein analizleri, pellet kısım ise yağ asidi, A, D, E ve K vitaminleri, kolesterol ve sterol analizleri için kullanıldı. 


\subsection{Deneysel Prosedürler}

\subsubsection{MDA tayini}

Lipit peroksidasyonunun en önemli göstergesi olan malondialdehit (MDA) düzeyi Okhawa ve arkadaşlarının tanımladıkları metotta bazı değişiklikler yapılarak spektrofotometrik olarak ölçüldü [15]. 1,0 mL alınan kas doku örneği üzerine $0,5 \mathrm{~mL} \% 8,1^{\prime}$ lik sodyum dodesil sülfat (SDS), $0,5 \mathrm{~mL} \% 0.8^{\prime}$ lik tiyobarbitürik asit (TBA), 1,0 $\mathrm{mL} \% 10^{\prime}$ luk trikloroasetik asit (TCA), $1,0 \mathrm{~mL}$ ( \% 20' lik glasiyel asetik asit/sodyum hidroksit $(\mathrm{NaOH}) \mathrm{pH} 3,5)$ ve $50 \mu \mathrm{L} \%$ 2' lik butil hidroksi toluen (BHT) eklendi ve bu karışım votrekslendi ve sonra $60 \mathrm{dk}$ kaynar su banyosunda $\left(95^{\circ} \mathrm{C}\right)$ bekletildi. Tüpler soğuduktan sonra tüplere $5 \mathrm{~mL}$ bütanol/piridin (1:15 oranında) ilave edildi ve sonra tüpler $1780 \times \mathrm{g}+4^{\circ} \mathrm{C}$ ' de $10 \mathrm{dk}$ santrifüj edildi. Santrifüjden sonra üsteki organik faz alınarak $532 \mathrm{~nm}$ dalga boyunda UV'de tüm örneklerin absorbansları okundu. Standart olarak 1.1',3.3'-tetraetoksipropan çözeltisi kullanıldı. Sonuçlar $\mathrm{nmol} / \mathrm{g}$ doku olarak hesaplandi.

\subsection{2 İndirgenmiş glutatyon (GSH) tayini}

GSH düzeyi Ellman tarafindan tanımlanan metoda göre yapıldı [16]. 1,0 mL kas doku örneği üzerine 1,0 mL \%10' luk TCA reaktifi ilave edildi ve sonra $10 \mathrm{dk} 2790 \times$ g'de santrifüj edilerek pellet çöktürüldü. Supernatant kısmı başka bir tüpe alındı. Supernatant kısım üzerine 1,0 mL 5,5' ditiobis 2- nitrobenzoik asit (DTNB) çözeltisi (\%1'lik sodyum sitrat içinde $30 \mathrm{mg}$ DTNB çözülerek hazırlandı) ve 0,3 M Disodyum fosfat $\left(\mathrm{Na}_{2} \mathrm{HPO}_{4}\right)$ çözeltisi ilave edildi, oluşan sarı renk $412 \mathrm{~nm}$ dalga boyunda UV'de blank'a karş1 örneklerin absorbansları okundu. Kalibrasyon eğrisi oluşturmak için saf GSH standart olarak kullanıldı [74].

\subsubsection{Doku Protein Tayini}

Doku protein miktarı Lowry ve arkadaşları tarafından tanımlanan metoda göre spektrofotometrik olarak ölçüldü [17]. Alınan $10 \mu \mathrm{L}$ kas doku örneğine Lowry çözeltisi ilave edildi ve $10 \mathrm{dk}$ beklendi, süre sonunda su ile seyreltilmiş folin reaktifi ilave edildi. $30 \mathrm{dk}$ 'a sonra $760 \mathrm{~nm}$ dalga boyunda UV'de blank'a karşı örneklerin absorbansları okundu. Bovin serum albümin standart olarak kullanıldı.

\subsubsection{Dokuda yağ asidi, A, D, E ve K vitaminleri, kolesterol} ve sterol tayini

İskelet kası doku örneklerinde yağ asidi, A, D, E ve K vitaminleri, kolesterol ve sterol ekstraksiyonu Hara ve Radin tarafından tanımlanan metoda göre yapıldı [18]. Bunun için, doku örnekleri 3:2 (v/v) oranında hekzanisopropanol karışımı ile homojenize edildi. Daha sonra bu homojenat $+4^{\circ} \mathrm{C}$ 'de $9050 \times$ g'de $10 \mathrm{dk}$ santrifüj edildi, elde edilen supernatant kısım yağ asidi, A, D, E ve K vitaminleri, kolesterol ve sterol analizleri için kullanıldı.

Doku yă̆ asidi bileşimini belirlemek için ayrılan örneklerin üzerine \% 2 'lik metanolik sülfürik asit ilave edildi ve vortekslenerek numune ile iyice karışması sağlandı. Bu karışım $55^{\circ} \mathrm{C}$ 'de 15 saat metilleşmeye bırakıldı [19]. Süre sonunda, tüpler oda sıcaklığına kadar soğutuldu ve \% 5'lik sodyum klorür $(\mathrm{NaCl})$ ilave edilerek iyice karıştırıldı. Tüpler içinde oluşan yağ asidi metil esterleri hekzan ile ekstre edildi ve hekzan fazı üsten pipetle alınarak \% 2'lik potasyum bikarbonat $\left(\mathrm{KHCO}_{3}\right)$ ile muamele edildi ve faz ayrımı için 4 saat beklenildi. Daha sonra metil esterlerini içeren karışımlar, $45^{\circ} \mathrm{C}$ 'de, azot gazı kullanılarak çözücüleri uçuruldu ve kalan tortu 1,0 mL n-heptanda çözüldü ve yağ asidi metil esterleri SHIMADZU GC 17 gaz kromatografisi ile analiz edildi. Bu analiz için SPTM-2380 kapiller GC kolunu (L $\times$ I.D. $30 \mathrm{~m} \times 0.25$ $\mathrm{mm}$, df $0.20 \mu \mathrm{m}$ ) (Supelco, Sigma, USA) kullanıldı. Analiz sirasında kolon sicaklığ $120-220^{\circ} \mathrm{C}$, enjeksiyon sicaklığ $240^{\circ} \mathrm{C}$ ve dedektör sıcaklığ $280^{\circ} \mathrm{C}$ olarak tutuldu. Kolon sicaklığı $120^{\circ} \mathrm{C}$ 'den $220^{\circ} \mathrm{C}$ 'ye kadar ayarlandı. Taşıyıcı gaz olarak azot gazı kullanıldı. Analiz sırasında örneklere ait yağ asidi metil esterlerinin analizinden önce, standart yağ asidi metil esterlerine ait karışımlar enjekte edilerek, her bir yağ asidinin alıkonma süreleri belirlendi. $\mathrm{Bu}$ işlemden sonra gerekli programlama yapılarak örnekler ait yağ asidi metil esterleri karışımlarının analizi yapıldı.

A, D, E ve K vitaminleri, kolesterol ve sterol için alınan örneklerin üzerine $\% 5$ 'lik metanolik potasyum hidroksit $(\mathrm{KOH})$ çözeltisi ilave edildi. Örnekler vortekslendikten sonra $85{ }^{\circ} \mathrm{C}$ 'de $15 \mathrm{dk}$ bekletildi. Tüpler oda sıcaklığına kadar soğutuldu ve üzerine saf su ilave edildi ve karıştırıldı. Sabunlaşmayan lipofilik moleküller 2x5 mL hekzan ile ekstrakte edildi. Hekzan fazı azot gazı kullanılarak uçuruldu. Kalan tortu 1,0 mL (\%60+\%40,v/v) asetonitril/ metanol karışımında çözülerek otosampler viallerine alındı. Analiz, Shimadzu marka HPLC cihazı ile yapıldı. Cihazda pompa olarak LC-10 ADVP UV-visible, detectör olarak SPD-10A $V P$, kolon firın olarak CTO-10ASVP, otosampler olarak SIL-10ADVP, degasser ünitesi olarak DGU-14A ve Class VP software (Shimadzu, Kyota Japan). Mobil faz olarak asetonitril/metanol $(\% 60+\% 40$, v/v) karışımı kullanıldı. Mobil faz akış hızı 1,0 mL olarak belirlendi. Analiz için UV dedektör kullanıldı. Kolon olarak da Süpelcosil LC $18(15 \times 4.6 \mathrm{~cm}, 5 \mu \mathrm{m}$; Sigma, USA) kolonu kullanıldı. A vitamini için dedeksiyon dalga boyu $326 \mathrm{~nm}, \mathrm{E}$ vitamini için $202 \mathrm{~nm}$, D ve K vitaminleri için $265 \mathrm{~nm}$ olarak belirlendi [20,21]. 


\subsection{5 Ístatistik Analizi}

Verilerin istatistiksel analizi SPSS 15.0 paketi (SPSS Inc, Chicago, IL, USA) kullanılarak gerçekleştirildi. Parametrik testlerin ön şartlarını (ölçümlerin nicel olması, sonuçların ortalama şeklinde verilmesi, grupların rastgele ve birbirinden bağımsız seçilmesi, homojen olması vb. gibi) sağlayan değişkenlere ilişkin grup karşılaştırmalarında Tek Yönlü Varyans Analizi (ANOVA) ve Duncan çoklu karşılaştırma testi (DMRT) kullanılarak yapıldı [22]. Sonuçlar ortalama \pm standart hata olarak verildi. İstatistiksel anlamlılık düzeyi için $P$ değeri $p<0.05$ olarak kabul edildi.

\section{Bulgular}

Tip-1 diyabet oluşturulmuş sıçanların kas dokusunda MDA, GSH ve total protein düzeyindeki değişimler tablo 1' de gösterildi. Kontrol grubuna göre, STZ grubunda MDA düzeyinin anlamlı bir şekilde arttığı $(\mathrm{p}<0,001)$, GSH $(\mathrm{p}<$ $0,001)$ ve total protein $(\mathrm{p}<0,01)$ düzeylerinin anlamlı bir şekilde azaldığı belirlendi. STZ grubu ile karşılaştırıldığında, STZ+ÇY grubuna uygulanan çam yağı sonucunda MDA düzeyinin anlamlı bir şekilde azaldığı $(\mathrm{p}<0,001)$, GSH ve total protein düzeylerinin anlamlı bir şekilde $\operatorname{arttığı~}(\mathrm{p}<$ $0,001)$ tespit edildi.

Tablo 1. Tip-1 diyabet oluşturulmuş sıçanların kas dokusunda MDA, GSH ve total protein düzeyindeki değişime çam yağının etkisi

\begin{tabular}{cccc}
\hline & Kontrol & STZ & STZ+ÇY \\
\hline MDA & $10.13 \pm 0.17^{\mathrm{b}}$ & $13.88 \pm 0.18^{\mathrm{a}}$ & $10.56 \pm 0.16^{\mathrm{b}}$ \\
& & & \\
GSH & $1.19 \pm 0.02^{\mathrm{a}}$ & $0.22 \pm 0.01^{\mathrm{c}}$ & $0.74 \pm 0.01^{\mathrm{b}}$
\end{tabular}

Total Protein $\quad 48.45 \pm 0.53^{\mathrm{b}} \quad 46.25 \pm 0.42^{\mathrm{c}} \quad 50.84 \pm 0.41^{\mathrm{a}}$

Sonuçlar ortalama \pm standart $(\mathrm{n}=10)$ hata olarak verildi. [a-c: aynı satırda farklı harf taşıyan gruplar arasındaki farklılık istatistiksel bakımdan önemlidir $(\mathrm{P}<0,05)(\mathrm{DMRT})]$
Tablo 2. Tip-1 diyabet oluşturulmuş sıçanların kas dokusunda yağ asidi değişimine çam yağının etkisi (\%)

$\begin{array}{cccc} & \text { Kontrol } & \text { STZ } & \text { STZ }+ \text { ÇY } \\ & & & \\ \text { Palmitik asit 16:0 } & 23.04 \pm 0.17^{\mathrm{a}} & 19.50 \pm 0.25^{\mathrm{b}} & 17.81 \pm 0.20^{\mathrm{c}} \\ & & & \\ \text { Stearik asit 18:0 } & 5.92 \pm 0.11^{\mathrm{c}} & 10.98 \pm 0.18^{\mathrm{a}} & 7.59 \pm 0.22^{\mathrm{b}}\end{array}$

Oleik asit 18:1 $23.31 \pm 0.47^{\mathrm{b}} \quad 19.87 \pm 0.31^{\mathrm{c}} \quad 30.73 \pm 0.38^{\mathrm{a}}$

$\begin{gathered}\alpha \text {-Linolenik asit } \\ 18: 3\end{gathered} \quad 0.82 \pm 0.02^{\mathrm{a}} \quad 0.60 \pm 0.02^{\mathrm{b}} \quad 0.58 \pm 0.03^{\mathrm{b}}$

Araşidonik asit $\quad 6.42 \pm 0.31^{\mathrm{b}} \quad 9.66 \pm 0.20^{\mathrm{a}} \quad 5.06 \pm 0.18^{\mathrm{c}}$ $20: 4$

Dokosaheksaenoik $\quad 1.91 \pm 0.04^{\mathrm{b}} \quad 3.41 \pm 0.10^{\mathrm{a}} \quad 2.04 \pm 0.05^{\mathrm{b}}$ asit 22:6

Sonuçlar ortalama \pm standart $(\mathrm{n}=10)$ hata olarak verildi. [a-c: aynı satırda farklı harf taşıyan gruplar arasındaki farklılık istatistiksel bakımdan önemlidir $(\mathrm{P}<0,05)(\mathrm{DMRT})]$

Deneysel Tip 1 diyabet oluşturulmuş sıçanların kas dokusunda yağ asidi değişimi tablo 2'de gösterildi. Kontrol grubu ile karşılaştırıldığında, STZ grubunun kas dokusunda palmitik, oleik ve $\alpha$-linolenik asit düzeylerinde anlamlı azalma ( $\mathrm{p}<0,001)$, stearik, araşidonik ve dokosaheksaenoik asit düzeylerinde anlamlı artışın $(\mathrm{p}<0,001)$ olduğu belirlendi. Linoleik asit düzeyinde ortaya çıkan değişikliğin istatistiksel olarak önemli olmadığı bulundu. STZ grubuna göre, STZ+ÇY grubunun kas dokusunda oleik (p < 0,001) ve linoleik $(\mathrm{p}<0,05)$ düzeylerinde belirgin bir artış, palmitik, stearik, araşidonik ve dokosaheksaenoik asit düzeylerinde belirgin bir azalışın ( $\mathrm{p}<0,001)$ olduğu saptand. $\alpha$-linolenik asit düzeyinde görülen değişikliğin istatistiksel olarak önemli olmadığı belirlendi. Kontrol 
grubu ile karşıllaştırıldığında, STZ+ÇY grubuna uygulanan çam yağının stearik, araşidonik ve dokosaheksaenoik asit düzeyleri üzerinde olumlu etki gösterdiği saptandı.

Tip 1 diyabet oluşturulmuş sıçanların kas dokusunda A, $\mathrm{D}$, E ve $\mathrm{K}$ vitaminleri, kolesterol ve sterol değişimi tablo 3'de gösterildi. Kontrol grubu ile karşılaştırıldığında, STZ grubunda $\delta$-tokoferol, vitamin $\mathrm{D}_{3}, \alpha$-tokoferol, retinol, vitamin $\mathrm{K}_{1}$, kolesterol ve sterol düzeylerinde önemli artışın $(\mathrm{p}<0,001)$ olduğu saptand1. STZ grubuna göre, STZ+ÇY grubunun kas dokusunda $\delta$-tokoferol, vitamin $\mathrm{D}_{3}$, retinol ve kolesterol düzeylerinde önemli azalma $(\mathrm{p}<0,001)$, $\alpha$-tokoferol $(p<0,05)$, stigmasterol $(p<0,01)$ ve $\beta$-sitosterol $(\mathrm{p}<0,001)$ düzeylerinde ise önemli artışın olduğu bulundu. Vitamin $K_{1}$ düzeyinde görülen değişikliğin istatistiksel olarak önemli olmadığı tespit edildi. Kontrol grubu ile karşılaştıııldığında, STZ+ÇY grubunda retinol, vitamin $\mathrm{D}_{3}$ değerlerinin Kontrol grubu değerine yaklaştığ ve kolesterol düzeyleri üzerinde ise çam yağının olumlu etkisinin olduğu tespit edildi.

Tablo 3. Tip-1 diyabet oluşturulmuş sıçanların kas dokusunda $\mathrm{A}, \mathrm{D}, \mathrm{E}$ ve $\mathrm{K}$ vitaminler, kolesterol ve sterol değişimi üzerine çam yağının etkisi $(\mu \mathrm{g} / \mathrm{g})$

\begin{tabular}{|c|c|c|c|}
\hline & Kontrol & STZ & STZ+ÇY \\
\hline$\delta$-Tokoferol & $0.47 \pm 0.07^{\mathrm{c}}$ & $2.73 \pm 0.16^{\mathrm{a}}$ & $1.50 \pm 0.03^{\mathrm{b}}$ \\
\hline Vitamin $\mathrm{D}_{3}$ & $0.52 \pm 0.05^{\mathrm{b}}$ & $0.84 \pm 0.05^{\mathrm{a}}$ & $0.46 \pm 0.03^{\mathrm{b}}$ \\
\hline$\alpha$-Tokoferol & $2.72 \pm 0.20^{\mathrm{c}}$ & $43.75 \pm 1.67^{b}$ & $49.56 \pm 2.01^{\mathrm{a}}$ \\
\hline Retinol & $1.26 \pm 0.08^{\mathrm{b}}$ & $1.83 \pm 0.10^{\mathrm{a}}$ & $1.00 \pm 0.06^{\mathrm{b}}$ \\
\hline Vitamin $\mathrm{K}_{1}$ & $0.46 \pm 0.04^{b}$ & $1.20 \pm 0.04^{\mathrm{a}}$ & $1.10 \pm 0.04^{\mathrm{a}}$ \\
\hline $\begin{array}{c}\text { Kolesterol } \\
\mu \mathrm{mol} / \mathrm{g}\end{array}$ & $0.63 \pm 0.02^{\mathrm{c}}$ & $1.86 \pm 0.01^{\mathrm{a}}$ & $1.62 \pm 0.02^{\mathrm{b}}$ \\
\hline Stigmasterol & $93.74 \pm 1.66^{\mathrm{c}}$ & $230.72 \pm 3.44^{b}$ & $253.33 \pm 10.67$ \\
\hline$\beta$-sitosterol & $2.80 \pm 0.12^{\mathrm{c}}$ & $6.77 \pm 0.23^{\mathrm{b}}$ & $7.96 \pm 0.19^{\mathrm{a}}$ \\
\hline
\end{tabular}

Sonuçlar ortalama \pm standart $(\mathrm{n}=10)$ hata olarak verildi. [a-c: aynı satırda farklı harf taşıyan gruplar arasındaki farklılık istatistiksel bakımdan önemlidir $(\mathrm{P}<0,05)(\mathrm{DMRT})]$

\section{Tartışma}

Son yıllarda, diyabet ve diyabetle ilişkili komplikasyonların tedavisi ile önlenmesine yönelik yapılan çalışmalara yoğun bir ilgi bulunmakta, bitkiler sahip oldukları çeşitli aktif bileşiklerden dolayı bu tarz çalışmaların odağı durumundadırlar $[23,24]$.

STZ'nin neden olduğu diyabet, oksidatif hasara neden olan reaktif oksijen türlerinin (ROS) üretimi ile ilişkilidir. Deney hayvanlarında STZ'nin oksidatif stres aracilığ ile diyabete özgü komplikasyonları oluşturabildiği gösterilmiştir. Lipit peroksidasyon, çoklu doymamış yağ asitlerinde oksidatif bozulmaya yol açan serbest radikal kaynaklı bir süreçtir. Normal fizyolojik şartlarda, dokularda lipit peroksit düzeyi düşük konsantrasyonlarda bulunur, fakat patolojik durumlarda lipit peroksit düzeyi artmaktadır. Yapılan çalışmalarda göstermiştir ki, antioksidan bileşiklerin hücresel antioksidan savunma mekanizmalarını destekleyerek aktiviteleri azalan bu mekanizmaların aktivitelerini tekrar eski haline getirebildikleri, sonuçta lipit peroksidasyonunu engelleyerek oksidatif hasara karşı dokuları koruyabildikleri ifade edilmiştir [25].

Yaptığımız çalışmada çam yağının kan glukoz düzeyinin azaltılmasında yararlı etkiler gösterdiğini rapor ettik [10]. Elde ettiğimiz bulgulara göre, STZ grubunun kas dokusunda MDA düzeyinin arttığı, uyguladığımız çam yağı neticesinde MDA düzeyinin azalarak kontrol grubu değerlerine yaklaştığı belirlendi (Tablo 1). Çam yağında bulunan bazı aktif bileşiklerin serbest radikal temizleme özellikleri ile kas dokusunda MDA düzeyini azalttı̆̆ını söyleyebiliriz. Daha önce yapılan çalışmalarda da deneysel diyabette kas dokusunda MDA düzeyinin arttığı $[3,26]$, bu bakımdan elde ettiğimiz bulgunun daha önceki bulgularla paralellik gösterdiği görülmektedir. Yapılan bir çalışmada çam yağında terpen bileşiklerinin yoğun bir şekilde bulunduğu [12] ve bileşiklerin önemli antioksidan özellikleri olduğu belirlenmiştir [27,28]. Bir terpen olan D-limonenin antioksidan aktiviteye sahip olduğu, deneysel diyabette antidiyabetik özellikler gösterdiği [29,30] ayrıca dislipidemi ve hiperglisemi gibi metabolik bozuklukların önlenmesi ve iyileştirilmesinde yararlı etkileri olabileceği ifade edilmiştir [31].

Serbest radikallerin oluşturduğu oksidatif hasar karşı glutatyon, dengeleyici endojen antioksidan olarak aktivite göstermektedir. Bilindiği gibi GSH, hücrelerin normal yapısı ile redoks hemostazının korunmasına, serbest radikallerin bertaraf edilmesine ve detoksifikasyon reaksiyonlarına katılmaktadır [32]. Elde ettiğimiz bulgulara göre diyabetik 
sıçanların kas dokusunda GSH seviyesinin azaldığı (Tablo 1), muhtemelen kas hücreleri tarafından GSH kullanımının atması, GSH sentezinin azalması ya da diyabette artan oksidatif stres nedeni ile GSH metabolizmasının bozulmasına bağlı olarak bu azalma ortaya çıkmış olabilir. Diyabetik sıçanlara uyguladığımız çam yağı içinde bulunan antioksidan aktif bileşiklerin antioksidan savunma sisteminin aktivitesini desteklemesi ya da oksidatif stresi azaltması neticesinde GSH metabolizmasında düzelmelerin ortaya çıkması neticesinde kas dokusunda GSH düzeyinin arttığını düşünmekteyiz (Tablo 1). STZ verilerek diyabetik yapılan sıçanların kas dokusunda GSH düzeyinin azaldığı, uygulanan yüksek dozC vitaminin sonucunda $\mathrm{GSH}$ düzeyinin arttığı ifade edilmiştir [3]. Yapılan çalışmalarda diyabetik sıçanlara verilen çeşitli bitkisel özütlerin dokularda oksidatif stres göstergelerinde oluşan anormallikleri azalttıkları ya da önledikleri yapılan çalışmalarda ortaya çıkmıştır [26,33,34].

Yağ asitleri, her hücrenin yapısı ve fonksiyonu için gerekli olmalarının yanı sıra hücre zarının en önemli bileşenleridirler. Hem deneysel hem de doğal olarak gelişen diyabette çeşitli dokuların yağ asidi kompozisyonlarında değişikliklerin olduğu bildirilmiştir [35,36]. Elde ettiğimiz bulgulara göre, diyabetik sıçanların kas dokusunda palmitik asit düzeyinin azaldığı, stearik asit düzeyinin arttığı buna karşın, uygulanan çam yağı sonucunda palmitik ve stearik asit düzeylerinin azaldığı belirlendi (Tablo 2). Çam yağının stearik asit düzeyinde ortaya çıkan anormallikleri azalttığı tespit edildi. Glukoz, iskelet kasına insüline bağımlı mekanizmalar ile alınmaktadır. Diyabet gibi metabolik hastalıklarda insülin düzeyinin azalması yağ asidi sentezinin düzenleyicisi ve hız kısıtlayıcı enzimi olan asetil CoA karboksilaz aktivitesini baskıladığı bundan dolayı yağ asidi sentezinin azaldığ 1 ifade edilmiştir [37,38]. Kontrol grubuna göre STZ grubunda palmitik asit düzeyinin azalması, bu enzimin aktivitesinde görülen azalmayla ilişkili olabilir. Çünkü diyabette, stearik asit ve diğer total doymuş yă asitlerinin öncelikli sentezi söz konusudur [39]. Daha önce yapılan çalışmalarda da diyabetik sıçanların kas dokusunda palmitik asit düzeyinin azaldığı, stearik asit düzeyinin arttığı bildirilmiştir [40,41]. Bu bakımdan elde ettiğimiz bulguların önceki çalışma bulguları ile paralellik gösterdiği görülmektedir. Elde ettiğimiz bulgulara göre, oleik asit düzeyinin kontrol grubuna göre STZ grubunda azaldığı, uygulanan çam yağı sonucunda oleik asit düzeyinin arttığı belirlendi (Tablo 2). Daha önce yapılan çalışmalarda da oleik asit düzeyinin STZ grubunda azaldığ 1 rapor edilmiş [42,43], bu bakımdan elde ettiğimiz bulgunun önceki çalışma bulgularıyla uyum gösterdiği görülmektedir. Tekli doymamış yağ asitlerinin sentezi Stearoil-CoA desaturaz (SCD) aktivitesi ile gerçekleşmektedir. Diyet, hormonal ve çevresel faktörlerin kas dokusunda SCD aktivitesine etkileri bulunmaktadır. Diyetsel faktörler arasında yer alan glukoz ve çoklu doymamış yağ asidi (PUFA) konsantrasyonunun iskelet kasında SCD ekspresyonu üzerinde önemli etkileri olduğu ifade edilmiştir [44]. Çam yağında bol miktarda bulunan tekli ve çoklu doymamış yağ asitlerinin [43], SCD aktivitesini etkilemesinden dolayı STZ+ÇY grubunun kas dokusunda oleik asit düzeyinin arttığını düşünmekteyiz. Yapılan çalışmalarda da diyabetik sıçanlara uygulanan bazı aktif bileşiklerin yağ asidi sentezine katılan enzimlerin aktiviteleri üzerinde etkileri olduğu rapor edilmiştir [44]. Elde ettiğimiz bulgulara göre, kontrol grubu ile karşılaştırıldığında STZ grubunda linoleik, $\alpha$-linolenik, araşidonik ve dokosaheksaenoik asit (PUFA) düzeylerinde önemli değişikliklerin olduğu, uygulanan çam yağı sonucunda araşidonik ve dokosaheksaenoik asit düzeylerinde oluşan artışların azaltarak kontrol grubu değerlerine yaklaştırdığı belirlendi (Tablo 2). Çoklu doymamış yağ asidi sentezi delta 6 ve delta 5 desaturaz enzimlerinin aktivitesi ile gerçekleşmekte ve bu enzimlerin aktivitesini insülin hormonu regüle etmektedir $[41,45]$. İskelet kas1, insülinin etkisinin yoğun olduğu dokulardan biridir ve insülin düzeyinde oluşan değişiklikler hem deneysel hem de doğal diyabette kas yağ asidi kompozisyonunda önemli değişikliklerin oluşmasına neden olmaktadır [46,47]. Ayrıca diyetle alınan çoklu doymamış yağ asitlerinin $\Delta 6$-desatüraz dahil olmak üzere çeşitli lipojenik enzimlerin aktivite ve ekspresyonlarını baskıladığı bilinmektedir $[48,49,50]$. İncelediğimiz parametrelerde ortaya çıan değerlerin, diyabetik sıçanlarda insülin düzeyinin azalması ile çam yağının içeriğinde bol miktarda bulunan çoklu doymamış yağı asitlerinin etkisine bağlı olarak ortaya çıkmış olabilir. Yapılan çalışmalar incelendiğinde çam kabuğundan izole edilen ve piknogenol olarak adlandırılan fenolik bileşiğin diyabetik sıçanlarda kan glukoz düzeyini insülin dış1 mekanizmalarla azalttığı ve insülin salgılanması üzerinde etkisinin sınırlı kaldığı belirlenmiş̧tir [51,52].

Kolesterol tüm omurgalı hücrelerinde mevcut olup, yapı elemanı olarak işlev görmekte ve hücre membranlarının yapısını oluşturan çift katlı lipit tabakasının akışkanlığını düzenlemektedir. Aynı zamanda kolesterol, safra asitleri, steroid hormonlar ve oksisterollerin de öncüsüdür [53]. Kolesterol biyosentezinin hızı sınırlayıcı aşaması 3-hidroksi3-metil-glutaril-CoA redüktaz (HMG-CoA redüktaz) tarafindan katalizlenmekte, ancak skualen sentaz'ında bu süreçte önemli düzenleyici rolü bulunmaktadır [54]. 
Sterol düzenleyici element bağlayıcı proteinler (SREBPs) kolesterol, yağ asidi ve trigliserid biyosentezini düzenleyen en önemli transkripsiyon faktörleridir. Bu yönde yapılan çalışmalarda, insülinin bu transkripsiyon faktörünün en önemli düzenleyicisi olduğunu ortaya çıkarmıştır [55]. Elde ettiğimiz bulgulara göre, STZ grubunda kolesterol düzeyinin arttığı, uygulanan çam yağı sonucunda kolesterol düzeyinde azalmanın olduğu fakat bu azalmanın sınırlı kaldığı belirlendi (Tablo 3). STZ, langerhans adacıklarında bulunan ve insülin üreten $\beta$-hücrelerini tahrip ederek bu hücrelerin salgıladığı insülin miktarında azalmaya yol açarak hiperglisemik bir durumun ortaya çıkmasına sebep olmaktadır. Sonuçta kanda insülin düzeyi azalır, glukoz düzeyi artar [30]. İnsülin düzeyinde ortaya çıkan azalma kolesterol biyosentezine katılan enzimler ile transkripsiyon faktörünün aktivitesini engellemesi neticesinde kas dokusunda kolesterol düzeyi artmış olabilir. Çam yağında bulunan bazı aktif bileşiklerin kolesterol biyosentezi üzerindeki sınırlı etkileri neticesinde kolesterol düzeyinde ortaya çıkan anormalliklerin azaltılmasında olumlu etkileri olduğunu söyleyebiliriz. Bitkilerde bulunan fitosterol ve fitostanollerin kan kolesterol düzeyini düşürücü etkileri olduğu ve çoklu sterol düzenleyici genlerin ekspresyonları üzerinde engelleyici etkiler göstererek kolesterol metabolizmasında ortaya çıkan anormallikleri engelledikleri ifade edilmiştir [56]. Yüksek sukroz diyeti uygulanmış sıçanlara $\alpha$-linolenik asit bakımından zengin Salba (Salvia hispanica) tohumunun verilmesi sonucunda ortaya çıkan metabolik anormalliklerin azaldığı rapor edilmiştir [57]. Yapılan çalışmalarda bitkilerde bulunan aktif bileşiklerin kolesterol ve trigliserit metabolizmasında ortaya çıan anormalliklerin düzeltilmesinde yararlı etkiler gösterdiği rapor edilmiştir [58,59].

Fitosterol ve fitostanoller (sitosterol, kampesterol ve stigmasterol) bitkisel besinlerde yaygin olarak bulunan aktif bileşiklerdir. Fitosterollerin, bağırsaklarda kolesterol emilimini engelleyerek kolesterol düzeyini azaltıcı etkileri bulunmaktadır [60]. Yaptığımız çalışmada STZ ve STZ+ÇY grubunda sterol düzeyinin arttığını belirledik (Tablo 3). Kolesterolce zengin diyet uygulanan sıçanların iskelet ve kalp kasında sitostenol düzeyinin, iskelet kasında ise stigmasterol ve sitosterol düzeyinin arttığı belirlenmiştir [61]. Fitosterolce zengin beslenen sıçanların kas dokusunda da sterol düzeyinin arttığı belirlenmiştir [62]. Çam yağının stigmasterol ve $\beta$-sitosterol bakımından zengin olduğu rapor edilmiştir[43].

Elde ettiğimiz bulgulara göre, STZ grubunda retinol düzeyinin arttı̆̆ , STZ+ÇY grubunda ise retinol düzeyinin azalarak kontrol grubu değerlerine yaklaştığı tespit edildi (Tablo 3). Retinol, retinol taşıyıcı proteinler vasıtasıyla taşınmakta, farelerin serumunda retinol taşıyıcı protein aktivitesinin artması, karaciğerde glukoz üretiminin artmasına sebep olmakta, buda iskelet kasında insülin sinyal metabolizmasının bozulmasına yol açmaktadır $[63,64,65]$. İnsülin sinyal metabolizmasında ortaya çıkan bozulma neticesinde STZ grubunun kas dokusunda retinol düzeyinin arttığı, uygulanan çam yağının insülin sinyal metabolizması üzerindeki olumlu etkilerine bağlı olarak retinol düzeyinin azaldığını söyleyebiliriz. Bitkilerde bulunan bazı aktif moleküllerin bu tarz etkiye sahip olduğu çalışmalarda ortaya çıkmıştır [66,67].

Diabetes mellitus, oksidatif stres ile ilişkili metabolik bir hastalıktır, antioksidan savunma sisteminde oluşan değişiklikler, mitokondrial enerji metabolizmasının bozulması bu hastalıkta reaktif oksijen türlerinin birikimine neden olmaktadır. $\alpha$-tokoferol düşük yoğunluklu lipoproteinlerin oksidasyonunu engelleyerek oksidatif stresin önlenmesinde önemli rolü olan lipofilik bir moleküldür [68]. Deneysel diyabet çalışmalarında deney hayvanlarının incelenen dokularında $\alpha$-tokoferol düzeyin arttığı tespit edilmiştir [69,72]. Beslenmeye bağlı olarak karaciğer, iskelet kası ve yă̆ dokusunda $\alpha$-tokoferol düzeyinin arttığı ifade edilmiştir [70,71]. Yaptığımız çalışmada da diyabetik sıçanların kas dokusunda tokoferol düzeyinin arttığını tespit ettik (Tablo 3). Kucharska ve arkadaşları, yaptıkları çalışmada diyabetik sıçanların kas dokusunda $\alpha$-tokoferol düzeyinde değişme olmadığını fakat miyokard dokusunda arttığını belirlemişler [72]. Kuželová ve arkadaşları da diyabetik sıçanlar ile yaptıkları çalışmalarda benzer sonuçlara ulaşmışlar [68]. Tokoferol düzeyinde ortaya çıkan bu durumun kronik oksidatif strese karşı antioksidan savunma sisteminin adaptif bir yanıt olduğunu düşünmekteyiz. Patolojik durumlarda vücudun bazı metabolik adaptasyonlar gösterdiği çalışmalarda ortaya çıkmıştır [73].

\section{Sonuç}

Elde ettiğimiz bulgular ışığında, diyabetten en fazla etkilenen dokulardan biri olan iskelet kasında STZ'nin oluşturduğu bazı biyokimyasal değişikliklere karşı çam yağının faydalı etkiler gösterdiği ortaya çıkmıştır.

\section{TEŞEKKÜR}

$\mathrm{Bu}$ çalışma Fırat Üniversitesi Bilimsel Araştırmalar Koordinatörlüğü tarafından desteklenmiştir (FÜBAP, Elazığ, Türkiye). 


\section{KAYNAKLAR}

[1] Xavier, S., Sadanandan, J., George, N., Paulose, C.S. (2012). $\beta 2$-Adrenoceptor and insulin receptor expression in the skeletal muscle of streptozotocin induced diabetic rats: Antagonism by vitamin $\mathrm{D}_{3}$ and curcumin. European Journal of Pharmacology, 687, 14-20.

[2] Gumieniczek, A., Hopkała, H., Wójtowicz, Z., Nieradko, M. (2001). Differences in antioxidant status in skeletal muscle tissue in experimental diabetes. Clinica Chimica Acta, 314, 39-45.

[3] Bulduk, E., Gönül, B., Ozer, C. (2006). Effects of vitamin $\mathrm{C}$ on muscle glycogen and oxidative events in experimental diabetes. Molecular and Cellular Biochemistry, 292, 131-137.

[4] Szkudelski, T. (2001). The mechanism of alloxan and streptozotocin action in $\beta$-cells of the rat pancreas. Physiol Res, 50, 536-546.

[5] Kurçer, Z., Karaoğlu, D. (2012). Deneysel diyabet modellerinde alloksan ve streptozotosin kullanımı. Türk Jem, 16, 34-40.

[6] Tuzlac1, E., Erol, M.K. (1999). Turkish folk medicinal plants. Part II: Eğridir (Isparta). Fitoterapia, 70, 593610.

[7] Kızılaslan, Ç., Sevgi, E. (2013). Ethnobotanical uses of genus Pinus L. (Pinaceae) in Turkey. Indian Journal of Traditional Knowledge, 12, 209-220.

[8] Baytop, T. (2001). Therapy with Medicinal Plants in Turkey (Past and Present), 1st ed. Istanbul University, Istanbul, 178-249.

[9] Ertuğ, F. (2004). Bodrum yöresinde halk tıbbında yararlanılan bitkiler. 14. Bitkisel ilaç hammaddeleri Toplantıs1 Bildiri Kitabı. Anadolu Üniversitesi Basımevi, Eskişehir, (29-31 Mayıs, 2002, Eskişehir), 76-93.

[10] Demir, E., Yılmaz, Ö. (2013). Streptozotosin ile Tip-2 diyabet oluşturulan sıçanlarda çam yağının antihiperglisemik ve bazı biyokimyasal parametrelere etkisi. Marmara Fen Bilimleri Dergisi, 25(3), 140156.

[11] Yesil-Celiktas, O., Ganzera, M., Akgun, İ., Sevimli, C., Korkmaz, K.S, Bedir, E. (2009). Determination of polyphenolic constituents and biological activities of bark extracts from different pinus species. J. Sci. Food Agric, 89, 1339-1345.

[12] Clark, S.P., Bollag, W.B., Westlund, K.N., Ma, F., Falls, G., Xie, D., Johnson, M., Isales, C.M., Bhattacharyya, M.H. (2014). Pine oil effects on chemical and thermal injury in mice and cultured mouse dorsal root ganglion neurons. Phytother Res, 28(2), 252-60.

[13] Biswas, M., Kar, B., Bhattacharya, S., Kumar, R.B., Ghosh, A.K., Haldar, P.K. (2011). Antihyperglycemic activity and antioxidant role of Terminalia arjuna leaf in streptozotocin-induced diabetic rats. Pharmaceutical Biology, 49(4), 335-340.

[14] Demir, E., Yilmaz, O., Ozsahin, A.D. (2013). The effect of some biochemical parameters in brain tissue of rats pine oil streptozotocin with experimental diabetes in rats. International Journal of Diabetes Research, 2(3), 39-44.

[15] Ohkawa, H., Ohishi, N., Yagi, K. (1979). Assay for lipid peroxides in animal tissues by thiobarbituric acid reaction. Anal Biochem, 95(2), 351-358.

[16] Ellman, G.L. (1959). Tissue sulfhydryl groups, Arch. Biochem. Biophys, 82, 70-77.

[17] Lowry, O.H., Rosebrough, N.J., Farr, A.L., Randall, R.J. (1951). Protein measurement with the Folin phenol reagent. J. Biol. Chem, 193(1), 265-275.

[18] Hara, A., Radin, N.S. (1978). Lipid extraction of tissues with a low-toxicity solvent. Analytical Biochemistry, 90(1), 420-426.

[19] Christie, W.W. (1992). Gas Chromatography and Lipids. Glaskow, The Oil Press.

[20] Katsanidis, E., Addis, P.B. (1999). Novel HPLC analysis of tocopherols and cholesterol in tissue. Free Radic. Biol. Med, 27, 1137-1140.

[21] Bragagnolo, N., Rodriguez-Amaya, D.B. (2003). Comparison of the cholesterol content of Brazilian chicken and quail eggs. J. Food Comp. Anal, 16, 147153.

[22] Duncan, D.B. (1957). Multiple ranges tests for correlated and heteroscedastic means. Biometrics, 13, 359-364.

[23] Patel, D., Prasad, S., Kumar, R., Hemalatha, S. (2012). An overview on antidiabetic medicinal plants having insulin mimetic property. Asian Pac J Trop Biomed, 2(4), 320-30.

[24] Jung, M., Park, M., Lee, H.C., Kang, Y.H., Kang, E.S., Kim, S.K. (2006). Antidiabetic agents from medicinal plants. Curr Med Chem, 13(10), 1203-1218.

[25] Kumar, P., Sharma, A., Varshney, P., Rao, C.V. (2013). Antidiabetogenic and antioxidant effects of Caralluma attenuata extract on streptozotocin induced diabetes in rats. Journal of Pharmacy Research, 7, 257-262. 
[26] Genet, S., Kale, R.K., Baquer, N.Z. (2002). Alterations in antioxidant enzymes and oxidative damage in experimental diabetic rat tissues: effect of vanadate and fenugreek (Trigonellafoenum graecum). Mol Cell Biochem, 236, 7-12.

[27] González-Burgos, E., Gómez-Serranillos, M.P. (2012). Terpene compounds in nature: a review of their potential antioxidant activity. Curr Med Chem, 19(31), 5319-5341.

[28] Türkez, H., Aydin, E. (2016). In vitro assessment of cytogenetic and oxidative effects of $\alpha$-pinene. Toxicol Ind Health, 32(1), 168-76.

[29] Murali, R., Karthikeyan, A., Saravanan, R. (2013). Protective effects of D-limonene on lipid peroxidation and antioxidant enzymes in streptozotocin-induced diabetic rats. Basic Clin Pharmacol Toxicol, 112, 175-181.

[30] Murali, R., Saravanan, R. (2012). Antidiabetic effect of D-limonene, a monoterpene in streptozotocininduced diabetic rats. Biomedicine \& Preventive Nutrition, 2, 269-275.

[31] Jing, L., Zhang, Y., Fan, S., Gu, M., Guan, Y., Lu, X., Huang, C., Zhou, Z. (2013). Preventive and ameliorating effects of citrus D-limonene on dyslipidemia and hyperglycemia in mice with highfat diet-induced obesity. Eur J Pharmacol, 5, 715(13): 46-55.

[32] Sefi, M., Fetoui, H., Lachkar, N., Tahraoui, A., Lyoussi, B., Boudawara, T, Zeghal, N. (2011). Centaurium erythrea (Gentianaceae) leaf extract alleviates streptozotocin-induced oxidative stress and $\beta$-cell damage in rat pancreas. Journal of Ethnopharmacology, 135, 243-250.

[33] Mishra, S.B., Verma, A., Vijayakumar, M. (2013). Preclinical evaluation of antihyperglycemic and antioxidant action of Nirmali (Strychnos potatorum) seeds in streptozotocin nicotinamide-induced diabetic Wistar rats: A histopathological investigation. Biomarkers and Genomic Medicine, 5, 157-163.

[34] Gandhi, G.R., Ignacimuthu, S., Paulraj, M.G. (2011). Solanum torvum Swartz. fruit containing phenolic compounds shows antidiabetic and antioxidant effects in streptozotocin induced diabetic rats. Food Chem Toxicol, 49(11), 2725-33.

[35] Tilvis, R.S. Miettinen, T.A. (1985). Fatty acid compositions of serum lipids, erythrocytes, and platelets in insulin-dependent diabetic women. J Clin Endocrinol Metab, 61(4), 741-5.
[36] Naresh Kumar, R., Sundaram, R., Shanthi, P., Sachdanandam, P. (2013). Protective role of 20$\mathrm{OH}$ ecdysone on lipid profile and tissue fatty acid changes in streptozotocin induced diabetic rats. Eur $J$ Pharmacol, 698, 489-498.

[37] Wakil, S.J., Abu-Elheiga, L.A. (2009). Fatty acid metabolism: target for metabolic syndrome. J. Lipid Res, 50, 138-143.

[38] Winder, W.W., Wilson, H.A., Hardie, D.G., Rasmussen, B.B., Hutber, C.A., Call, G.B., Clayton, R.D., Conley, L.M., Yoon, S., Zhou, B. (1997). Phosphorylation of rat muscle acetyl-CoA carboxylase by AMP-activated protein kinase and protein kinase A. J. Appl. Physiol, 82(1), 219-225.

[39] Vessby, B. (2000). Dietary fat and insulin actions in humans. Br J Nutr, 83, 91-6.

[40] Güvenç, M., Yılmaz, Ö., Tuzcu, M., Özşahin, A.D. (2009). Contribution of vitamin $\mathrm{C}$ and $\alpha$-lipoic acid and their combination on the products level of desaturase enzymes in the lung and muscle tissues of poorly controlled experimental diabetic rats. Research Journal of Biological Sciences, 4(6), 710-715.

[41] Yilmaz, O., Ersan, Y., Dilek Ozsahin, A., Ihsan Ozturk, A., Ozkan, Y. (2013). Consequences of the combined $\alpha$-tocopherol, ascorbic acid and $\alpha$-lipoic acid on the glutathione, cholesterol and fatty acid composition in muscle and liver of diabetic rats. Iran J Basic Med Sci, 16, 165-72.

[42] Dobrzyń, A., Dobrzyń, P. (2006). StearoylCoA desaturase--a new player in skeletal muscle metabolism regulation. J Physiol Pharmacol, 57 Suppl 10, 31-42.

[43] Demir, E. (2013). Tip-1 ve Tip-2 diyabet oluş̧urulmuş sıçanlarda hiperglisemi üzerine çam ve acı badem yağlarının etkileri. Doktora Tezi, Fırat Üniversitesi, Türkiye.

[44] Bal, R., Türk, G., Tuzcu, M., Yilmaz, O., Ozercan, I., Kuloglu, T., Gür, S., Nedzvetsky, V.S., Tykhomyrov, A.A., Andrievsky, G.V., Baydas, G., Naziroglu, M. (2011). Protective effects of nanostructures of hydrated $\mathrm{C}(60)$ fullerene on reproductive function in streptozotocin-diabetic male rats. Toxicology, 282, 69-81.

[45] Nakamura, M.T., Nara, T.Y. (2004). Structure, function, and dietary regulation of delta 6 , delta 5 , and delta 9 desaturases. Annu. Rev. Nutr, 24, 345-376.

[46] Rimoldi, O.J., Finarelli, G.S., Brenner, R.R. (2001). Effects of diabetes and insulin on hepatic $\Delta 6$ 
desaturase gene expression. Biochem Biophys Res Commun. 283(2), 323-6.

[47] Montanaro, M.A., Bernasconi, A.M., González, M.S., Rimoldi, O.J., Brenner, R.R. (2005). Effects of fenofibrate and insulin on the biosynthesis of unsaturated fatty acids in streptozotocin diabetic rats. Prostaglandins Leukot Essent Fatty Acids, 73, 369378.

[48] Jan, S., Guillou, H., D’Andrea, S., Daval, S., Bouriel, M., Rioux, V., Legrand, P. (2004). Myristic acid increases delta6-desaturase activity in cultured rat hepatocytes. Reprod. Nutr. Dev, 44, 131-140.

[49] Sato, M., Adan, Y., Shibata, K., Shoji, Y., Sato, H., Imaizumi, K. (2001). Cloning of rat $\Delta 6$-desaturase and its regulation by dietary eicosapentaenoic or docosahexaenoic acid. World Rev Nutr Diet, 88, 196199.

[50] Price, P.T., Nelson, C.M., Clarke, S.D. (2000). Omega-3 polyunsaturated fatty acid regulation of gene expression. Curr Opin Lipidol, 11, 3-7.

[51] Parveen, K., Ishrat, T., Malik, S., Kausar, M.A., Siddiqui, W.A. (2013). Modulatory effects of Pycnogenol $^{\circledR}$ in a rat model of insulin-dependent diabetes mellitus: biochemical, histological, and immunohistochemical evidences. Protoplasma, 250, 347-360.

[52] Parveen, K., Khan, M.R., Mujeeb, M., Siddiqui, W.A. (2010). Protective effects of Pycnogenol on hyperglycemia-induced oxidative damage in the liver of type 2 diabetic rats. Chemico-Biological Interactions, 186, 219-227.

[53] Leoni, V., Caccia, C. (2013). 24S-hydroxycholesterol in plasma: A marker of cholesterol turnover in neurodegenerative diseases. Biochimie, 95, 595-612.

[54] Do, R., Kiss, R.S., Gaudet, D., Engert, J.C. (2009). Squalene synthase: a critical enzyme in the cholesterol biosynthesis pathway. Clin Genet, 75, 19-29.

[55] Xiao, X., Song, B.L. (2013). SREBP: a novel therapeutic target. Acta Biochim Biophys Sin, 45, 2-10.

[56] Chen, Q., Gruber, H., Pakenham, C., Ratnayake, W.M., Scoggan, K.A. (2009). Dietary phytosterols and phytostanols alter the expression of sterolregulatory genes in SHRSP and WKY inbred rats. Ann Nutr Metab, 55, 341-350.

[57] Oliva, M.E., Ferreira, M.R., Chicco, A., Lombardo, Y.B. (2013). Dietary Salba (Salvia hispanica L) seed rich in $\alpha$-linolenic acid improves adipose tissue dysfunction and the altered skeletal muscle glucose and lipid metabolism in dyslipidemic insulin-resistant rats. Prostaglandins Leukot Essent Fatty Acids, 89(5), 279-89.

[58] Harnafi, H., Ramchoun, M., Tits, M., Wauters, J.N., Frederich, M., Angenot, L., Aziz, M., Alem, C., Amrani, S. (2013). Phenolic acid-rich extract of sweet basil restores cholesterol and triglycerides metabolism in high fat diet-fed mice: A comparison with fenofibrate. Biomedicine \& Preventive Nutrition, 3, 393-397.

[59] Harnafia, H., Azizb, M., Amrani, S. (2009). Sweet basil (Ocimum basilicum L.) improves lipid metabolism in hypercholesterolemic rats. e-SPEN, the European e-Journal of Clinical Nutrition and Metabolism, 4, 181-186.

[60] Jong, A., Plat, J., Mensink, R.P. (2003). Metabolic effects of plant sterols and stanols. $J$ Nutr Biochem, 14, 362-369.

[61] Connor, W.E., Lin, D.S., Pappu, A.S., Frohlich, J., Gerhard, G. (2005). Dietary sitostanol and campestanol: accumulation in the blood of humans with sitosterolemia and xanthomatosis and in rat tissues. Lipids, 40(9), 919-23.

[62] Alhazzaa, R., Oen, J.J.J., Sinclair, A.J. (2013). Dietary phytosterols modify the sterols and fatty acid profile in a tissue-specific pattern. Journal of Functional Foods, 5, 829-837

[63] Frey, S.K., Vogel, S. (2011). Vitamin A metabolism and adipose tissue biology. Nutrients, 3(1), 27-39.

[64] Wolf, G. (2007). Serum retinol-binding protein: a link between obesity, insulin resistance, and type 2 diabetes. Nutr Rev, 65(5), 251-6.

[65] Yang, Q., Graham, T.E., Mody, N., Preitner, F., Peroni, O.D., Zabolotny, J.M., Kotani, K., Quadro, L., Kahn, B.B. (2005). Serum retinol binding protein 4 contributes to insulin resistance in obesity and type 2 diabetes. Nature, 436 (7049), 356-62.

[66] Kim, T., Davis, J., Zhang, A.J., He, X., Mathews, S.T. (2009). Curcumin activates AMPK and suppresses gluconeogenic gene expression in hepatoma cells. Biochem Biophys Res Commun, 388 (2), 377-82.

[67] Soetikno, V., Sari, F.R., Sukumaran, V., Lakshmanan, A.P., Harima, M., Suzuki, K., Kawachi, H., Watanabe, K. (2013). Curcumin decreases renal triglyceride accumulation through AMPK-SREBP signaling pathway in streptozotocin-induced type 1 diabetic rats. J Nutr Biochem, 24 (5), 796-802. 
[68] Kuzelová, M., Adameová, A., Sumbalová, Z., Paulíková, I., Harcárová, A., Svec, P., Kucharská, J. (2008). The effect of simvastatin on coenzyme $\mathrm{Q}$ and antioxidant/oxidant balance in diabetichypercholesterolaemic rats. Gen. Physiol. Biophys, 27, 291-298.

[69] Jain, S.K., Levine, S.N. (1995). Elevated lipid peroxidation and vitamin E-quinone levels in heart ventricles of streptozotocin-treated diabetic rats. Free Radic Biol Med, 18(2), 337-41.

[70] Bjørneboe, A., Bjørneboe, G.E., Drevon, C.A. (1990). Absorption, transport and distribution of vitamin E. $J$ Nutr, 120 (3), 233-42.

[71] Rigotti, A. (2007). Absorption, transport, and tissue delivery of vitamin E. Mol Aspects Med, 28(5-6), 423-36.

[72] Kucharska, J., Gvozdjakova, A., Stefek, M., Sotnikova, R., Sumbalova, Z. (2001). Adaptive changes of antioxidant status in development of experimental diabetes. Bratisl Lek Listy, 102 (11), 515-519.

[73] Ferreira, F.M., Seiça, R., Oliveira, P.J., Coxito, P.M., Moreno, A.J., Palmeira, C.M., Santos, M.S. (2003). Diabetes induces metabolic adaptations in rat liver mitochondria: role of coenzyme $\mathrm{Q}$ and cardiolipin contents. Biochim Biophys Acta, 1639 (2), 113-20.

[74] Akerboom, T.P., Sies, H. (1981). Assay of glutathione, glutathione disulfide, and glutathione mixed disulfides in biological samples. Methods Enzymol, 77, 373-82. 